\title{
ANALYSIS OF THE PERFORMANCE OF TRANSIT AREA OF SIDOARJO STATION AS A TRANSIT ORIENTED DEVELOPMENT (TOD) AREA
}

\author{
Muhammad Hidayat Isa*, Adjie Pamungkas ${ }^{* *}$, Rima Dewi Suprihardjo ** \\ *) Master Student, Department of Architecture, Faculty of Civil Engineering and \\ Planning, Institute of Technology Sepuluh Nopember, Indonesia \\ **) Lecturer, Department of Urban and Regional Planning, Faculty of Civil Engineer- \\ ing and Planning, Institute of Technology Sepuluh Nopember, Indonesia \\ e-mail:dayatmhi@gmail.com*
}

\begin{abstract}
The solving of traffic congestion has led to innovative strategies that promote the integration of transport system, one of which is through the concept of Transit Oriented Development (TOD). The movement of the population with high use of private vehicles in Surabaya-Sidoarjo corridor has caused congestion problems. However, the efforts done are still focused on the improvement of the capacity of the road network. This effort is partial and temporal, which means that in the long term it will continue to cause problems. For the development of mass transit in the north-south corridor, specifically on the side of Surabaya, the transit area is already in the planning stages and brings the concept of TOD. Therefore, it is necessary to study and examine TOD in Sidoarjo side, especially in the transit area of Sidoarjo station, which has the highest passenger movement in the Surabaya-Sidoarjo corridor.

This study aims to analyze the performance of transit area of Sidoarjo Station as a TOD area. The analytical method used is descriptive statistical analysis and walkthrough analysis. Descriptive statistical analysis used includes the analysis of measures of central tendency, percentages and ratios, and graphs. Meanwhile, the walkthrough analysis used is the linear side view. Based on the analysis, the performance of transit area of Sidoarjo Station as TOD area is relatively low at $23.5 \%$. Only four of the seventeen variables meet the performance standards. Those four variables are BCR (Building Coverage Ratio), percentage of road way area, pedestrian way connectivity, and percentage of parking lot.
\end{abstract}

Keywords: Transit Oriented Development, transit area performance, Sidoarjo Station 


\begin{abstract}
ABSTRAK
Pemecahan masalah kemacetan lalu lintas telah mengarah pada strategi inovatif yang mengedepankan integrasi sistem tranportasi, salah satunya melalui konsep Transit Oriented Development (TOD). Pergerakan penduduk dengan penggunaan kendaraan pribadi yang tinggi di koridor Surabaya-Sidoarjo menyebakan permasalahan kemacetan. Namun, upaya penanganannya masih terfokus pada peningkatan kapasitas jaringan jalan. Upaya ini lebih bersifat parsial dan temporal di mana dalam jangka panjang akan tetap menimbulkan masalah. Khusus sisi Surabaya, pengembangan angkutan massal di koridor utara-selatan, kawasan transitnya sudah dalam tahapan perencanaan mengusung konsep TOD. Oleh karenanya, perlu dilakukan penelitian yang mengkaji TOD di sisi Sidoarjo terutama di kawasan transit Stasiun Sidoarjo yang memiliki bangkitan pergerakan penumpang tertinggi di koridor Surabaya-Sidoarjo.

Penelitian ini bertujuan untuk menganalisis kinerja kawasan transit Stasiun Sidoarjo sebagai kawasan TOD. Metode analisis yang digunakan adalah analisis statistik deskriptif dan analisis walkthrough. Analisis statistik deskriptif yang digunakan meliputi analisis ukuran pemusatan, persentase dan rasio, dan grafik. Sedangkan analisis walkthrough yang digunakan adalah linear side view Berdasarkan hasil analisis, kinerja kawasan transit Stasiun Sidoarjo sebagai kawasan relatif rendah yaitu 23,5\%. Hanya empat dari tujuh belas variabel kinerja yang memenuhi standard. Empat variabel yang dimaksud meliputi KDB, persentase luas jalan, konektivitas jalur pejalan kaki, dan persentase lahan parkir kendaraan bermotor.
\end{abstract}

Kata kunci: Transit Oriented Development, kinerja kawasan transit, Stasiun Sidoarjo

\title{
INTRODUCTION
}

The solving of traffic congestion has led to innovative strategies that promote the integration of transport system, one of which is through the concept of Transit Oriented Development (TOD). This concept aims to reduce the use of private vehicles, through the development of transit-oriented area, thus the movement can be more focused on the use of transit-based public transports and non-motorized modes (Dittmar dan Ohland, 2004). The implementation of TOD in the world shows the need for area planning around the transit points to influence the level of transit movement or the use of public transport so as to achieve the goal of overcoming the congestion of the city.

Surabaya city is the center of Surabaya Metropolitan Area (SMA) whose suburbs consist of Sidoarjo, Gresik, and Bangkalan. The rapid development of Surabaya triggers the high mobility of the population from suburbs to the core city and vice versa. One of the corridors with high population movement is the Surabaya-Sidoarjo corridor. It can be seen from the fullness level of the main road connecting Surabaya-Sidoarjo, namely Ahmad Yani Street, which reaches an average value of more 
than one (> 1) during rush hour (Surabaya Development Planning Agency, 2012). Some efforts to solve this congestion problem in Surabaya-Sidoarjo corridor have been conducted. However, there is a tendency that the government is only focused on increasing the capacity of the road network (Surabaya Development Planning Agency, 2012). That is a partial and temporal solution that will increase the high growth rate of the motor vehicles.

Referring to the briefing of Bappenas (National Development Planning Agency) (2012), one of the efforts to encourage the shifting of transport mode to public transport is by implementing TOD in the rail-based backbone system in urban areas in Indonesia, including Surabaya Metropolitan Area. The study shows that transit area in train station in Surabaya-Sidoarjo corridor is potential for the development of the concept of TOD (Isa, 2014). But this time, it's only the side of Surabaya that is being planned with TOD concept on its mass transit plan, including the train station area (World Bank, 2014). In fact, both Surabaya and Sidoarjo sides need to be developed to overcome the problems of congestion in Surabaya-Sidoarjo corridor.

Sidoarjo station is one of the stations traversed by commuter trains with high movement potential, 67,739 passengers in 2013 (PT Kereta Api Indonesia Daerah Operasi VIII, 2014). The number of passengers was recorded as the third-highest number of commuter users in Surabaya-Sidoarjo corridor and the highest in Sidoarjo. However, only about $34.78 \%$ of the total users come from a radius of 600 meters from Sidoarjo (Isa, 2014). Then, the use of land in the area of a radius of 600 meters around the Sidoarjo station is still less diverse, with $62 \%$ of it used as residential area. This fact indicates that Sidoarjo station area has not implemented the TOD concept. Thus, the concept of TOD needs to be developed in transit area of Sidoarjo Station to overcome the problems of congestion in Surabaya-Sidoarjo corridor. In terms of that, this study aims to analyze the performance of transit area of Sidoarjo Station as a TOD area.

\section{RESEARCH METHODS}

The first step in this research is primary and secondary data collection. Primary data collection was done using the primary survey in which the data was obtained from observations and questionnaires. In this study, the appropriate type of observation is controlled observation (structured observation), whose procedure and implementation are very tight and usually aided by sensitive tools and whose observation sheet uses controlling process which allows the observation to be re-conducted (Indrawati, et al, 2007). The type of questionnaire used is a combination of open structured questionnaires and closed structured questionnaires. Meanwhile, secondary data collection was done using secondary survey in which the data was obtained from data search results from relevant institutions (institutional survey) and through satellite imagery observation with the help of Google Earth and GIS applications.

Primary data include BCR (Building Coverage Ratio), the number of floors of the buildings, land use, the pattern of road network, pedestrian way connectivity, the availability of pedestrian way with shade, motor vehicle parking area, transport mode to reach the train station, the comfort level of the pedestrian ways, and the ori- 
entation of buildings along the pedestrian way. Secondary data include residential density data, land cover, population density, employment density, land prices, availability of main and supporting transport, the road functions, and safe road for bicycles.

The collected data was analyzed using descriptive statistical analysis techniques and walkthrough analysis.

1. Descriptive Statistics

The descriptive statistical analysis used includes the analysis of the measures of central tendency, percentages and ratios, and graphical analysis. The measures of central tendency are a single value that represents a data set and shows the characteristics of the data (Walpole, 1995). The size of central tendency consists of the mean, mode, and median. Meanwhile, percentage and ratio is a measure of comparison of a value. The analysis of the graphs is used to search or find patterns and correlation among variables. In this analysis, the graphs used were bar and circle graphs.

The variables in the target which used mean and median analysis are the BCR, population density, the number of floors of the buildings, population density, employment density, the percentage of transport mode to reach the train station, and the comfort level of the pedestrian ways. The variables which used modus analysis are the proportion of residential and non-residential land use, the pattern of the road network, and the percentage of transport mode to reach the train station. In addition, most of the variables of the study also used the analysis of percentages and ratios as well as bar and circle graphs.

2. Walkthrough Analysis

Walkthrough analysis in this study used a linear-type side view. This is because the need of the research was the observation of a front and side of the building, with serial vision in each road corridor and pedestrian way (Urban Design Toolkit, 2006 in Agustin, 2013). The comfort level of the pedestrian way and orientation of buildings along the pedestrian way were analyzed by observing and seeing the impression of each of the benchmarks felt along the roads and pedestrian ways. From these observations, in terms of impressions of comfort level are measured by width of the sidewalk, the availability of shelters, the absence of barriers, continuity, and the availability of road crossing facilities (Kusbiantoro, 2007).

Meanwhile, in terms of orientation of the buildings along the pedestrian way, it can be measured from tendency impression of the building orientation towards the pedestrian ways in the research area which are the space between the buildings and the pedestrian ways, the absence of partition between buildings and pedestrian ways, and the visual penetration from the pedestrian ways into the building (The City of Calgary Land Use Planning and Policy, 2004 and Institute for Transportation and Development Policy, 2014).

After analyzed, the value of each variable was then compared to the performance standard to measure the performance of TOD area. Based on the identification, which is reviewed from area function and the type of public transport passing the transit area, it is found that transit area of Sidoarjo Station is TOD community 
centers served by heavy rails as the main mode. The performance standards of TOD community centers can be seen in Table 1 .

Table 1. Community Centers TOD

\begin{tabular}{|c|c|c|}
\hline Indicators & Variables & Standards \\
\hline \multirow{4}{*}{$\begin{array}{l}\text { Land use } \\
\text { density in } \\
\text { TOD area }\end{array}$} & BCR & $60 \%-70 \%$ \\
\hline & Residential density & $86-161$ units/ ha \\
\hline & Number of floors of the building & $>3$ stories \\
\hline & Built land coverage & $80 \%-90 \%$ \\
\hline \multirow{4}{*}{$\begin{array}{l}\text { Population } \\
\text { density in } \\
\text { TOD area } \\
\text { Land use di- } \\
\text { versity in TOD } \\
\text { area }\end{array}$} & Population density & 247-358 persons/ ha \\
\hline & Employment density & 161-222 persons/ ha \\
\hline & Mix of uses ( $\%$ residential, $\%$ non residential) & $\begin{array}{l}45 \% \text { residential / } 55 \% \\
\text { non-residential }\end{array}$ \\
\hline & Diversity of land prices & Diverse \\
\hline \multirow[t]{5}{*}{$\begin{array}{l}\text { Transportation } \\
\text { facilities and } \\
\text { infrastructures } \\
\text { in TOD area }\end{array}$} & Percentage of road way area & $\begin{array}{l}<20 \% \\
\text { Grid with blok's cir- } \\
\text { cumference length } \leq \\
600 \text { meters }\end{array}$ \\
\hline & Pedestrian way connectivity & $\geq 90 \%$ \\
\hline & Availability of pedestrian way with shade & $\geq 75 \%$ \\
\hline & $\begin{array}{l}\text { Percentage of total street segments with safe } \\
\text { cycling conditions (speed } \leq 30 \mathrm{~km} / \text { hour) }\end{array}$ & $\geq 90 \%$ \\
\hline & Percentage of parking lot & $\leq 15 \%$ \\
\hline \multirow{3}{*}{$\begin{array}{l}\text { Pedestrian- } \\
\text { friendly TOD } \\
\text { area design }\end{array}$} & Percentage of mode share to reach station & Majority walking \\
\hline & Comfortable level of pedestrian way & Comfort \\
\hline & Bulding orientation along the pedestrian way & $\geq 50 \%$ \\
\hline
\end{tabular}

Indicator of land use density in TOD area consist of Building Coverage Ratio (BCR), residential density (number of residential units/ ha), number of floors of the building, and built land coverage in TOD area (Widyahari dan Indradjati, 2014; Renaissance planning group, 2011; Curtin, 2009; and Dittmar dan Ohland, 2004). Indicator of population density in TOD area consist of population density and employment density (number of employment/ ha) (Renaissance planning group, 2011). Indicator of land use diversity in TOD area consist of percentage of mix of uses among residential and non residential land use and diversity of land prices where the more it close to the station the more high is the land price and vice versa (Dittmar dan Ohland, 2004 and Renaissance planning group, 2011). Indicator of transportation facilities and infrastructures in TOD area consist of percentage of road way area (number of road way area divide total area), street pattern, pedestrian way connectivity (number of street segments with pedestrian way divide total street segments), availability of pedestrian way with shade (number of street segments with pedestrian way and have shade divide total street segments), percentage of total street segments with safe cycling conditions (speed $\leq 30 \mathrm{~km} /$ hour) (total street segments with safe 
cycling conditions divide total street segments), percentage of parking lot area (total parking lot area divide total area) (Institute for Transportation and Development Policy, 2014). Indicator of pedestrian-friendly TOD area design consist of percentage of mode share to reach station, comfortable level of pedestrian way, and bulding orientation along the pedestrian way (Dittmar dan Ohland, 2004 and Institute for Transportation and Development Policy, 2014). More details about the location of the transit area of Sidoarjo Station can be seen on Figure 1.

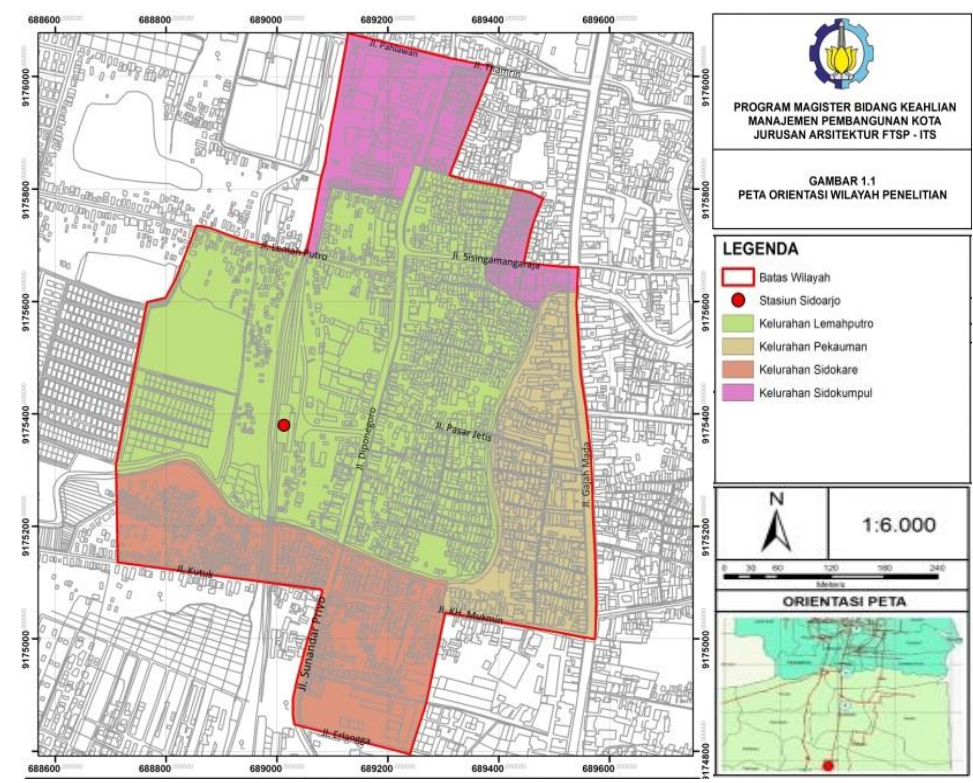

Figure 1. Transit Area of Sidoarjo Station

\section{RESULTS AND DISCUSSION}

\section{Land Use Density in TOD Area}

The analysis showed that of the four variables in the indicator of land use density in TOD area, only variable of BCR in transit area of Sidoarjo Station meets the standard of land density of TOD community center. This result indicates that in terms of building density, transit area of Sidoarjo Station meets the standard of TOD area density but the density dimensions (number of floors of the building) still does not characterize the standard of TOD. Besides, the number of housings per hectare (residential density) does not meet the standard either. This cannot be separated from the fact that area density dimension is dominated by single-storey residential building. Thus, although in general this transit area looks dense, in terms of quantity of the residential density, this transit area does not meet the standards of TOD area. In terms of percentage of built land coverage, transit area of Sidoarjo Station also does not meet the standards of TOD area, which means that there is still some land area that should be developed in order to support this area as a TOD area. More details can be seen in Table 2 and Figure 2. 
Table 2. Performance of Transit Area of Sidoarjo Station based on Indicator of Land Use Density in TOD Area

\begin{tabular}{lcc}
\hline \multicolumn{1}{c}{ Variables } & Standards & Existing \\
\hline BCR & $60 \%-70 \%$ & $\geq 60 \%$ \\
Residential density & $86-161$ units/ ha & 48 units/ ha \\
Number of floors of the building & $>3$ stories & 1 storey \\
Built land coverage & $80 \%-90 \%$ & $77,61 \%$ \\
\hline \multicolumn{4}{c}{}
\end{tabular}

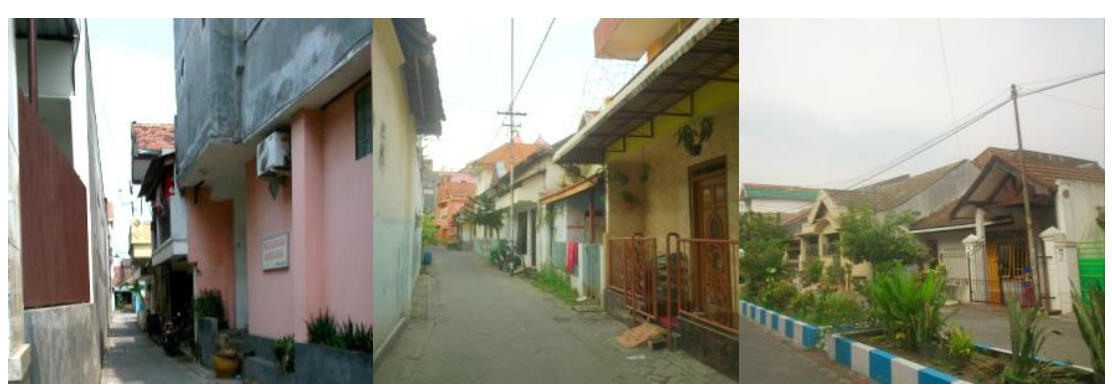

Figure 2. Characteristic of Land Use Density in Transit Area of Sidoarjo Station Source: field survey, 2014

\section{Population Density in TOD Area}

The analysis showed that of the two variables in the indicator of population density in TOD area, there is no variable that meets the standard of population density of TOD community center. This result indicates that population density, both population density in general and employment density, in transit area of Sidoarjo Station still does not characterize the population density of TOD area. If analyzed, this result is related with variable of residential density that does not meet the standard of TOD area. This means that, the residential density that does not meet the standard (lack of density) impacts on the population density that inhabit the area. Besides, the employment density that does not meet the standard of TOD area is also affected by the lack of land use for trade, service, and office, which triggers the high number of labors living around the TOD area. More details can be seen in Table 3 .

Table 3. Performance of transit area of Sidoarjo Station based on indicator of population density in TOD area

\begin{tabular}{lcc}
\hline \multicolumn{1}{c}{ Variables } & Standards & Existing \\
\hline Population density & $247-358$ persons/ ha & 190 persons/ ha \\
Employment density & $161-222$ persons/ ha & 97 persons/ ha \\
\hline & Source: Analysis result, 2014
\end{tabular}

3. Land Use Diversity in TOD Area

The analysis showed that of the two variables in the indicator of land use diversity in TOD area, there is no variable that meets the standard of land use diversity 
of TOD community center. This result indicates that the land use diversity in transit area of Sidoarjo Station does not characterize the land use diversity in TOD area. This condition is also affected by the high percentage of residential land use in transit area of Sidoarjo Station. Besides, the less diverse land use around Sidoarjo Station shows that the development of this area is not concentrated in the growth point around Sidoarjo Station. More details can be seen in Table 4 and Figure 3.

Table 4. Performance of transit area of Sidoarjo Station based on indicator of land use diversity in TOD area

\begin{tabular}{lcc}
\hline \multicolumn{1}{c}{ Variables } & Standards & Existing \\
\hline Mix of uses (\% residential, \% & $45 \%$ residential / & $48 \%$ residential/ 52\% \\
non residential) & $55 \%$ non-residential & non-residential \\
Diversity of land prices & Diverse & Not diverse \\
\hline & Source: Analysis result, 2014 &
\end{tabular}

4. Transportation Facilities and Infrastructures in TOD Area

The analysis showed that of the six variables in the indicator of transportation facilities and infrastructure in TOD area, there are three variables that meet the standard. This result indicates that transportation facilities and infrastructure in transit area of Sidoarjo Station do not characterize the transportation facilities and infrastructure in TOD area. This result is also affected by the street pattern in transit area of Sidoarjo Station which has no grid and tends to rotate due to barrier or partition that divides the road and breaks the connection of the road in transit area. Besides, the failure to achieve the standard is also affected by the fact that the quality of pedestrian way and the road condition do not meet the standards of pedestrian way and cyclists track in TOD area. More details can be seen in Table 5 and Figure 4.

Table 5. Performance of transit area of Sidoarjo Station based on indicator of transportation facilities and infrastructures in TOD Area

\begin{tabular}{|c|c|c|}
\hline Variables & Standards & Existing \\
\hline Percentage of road way area & $<20 \%$ & $11,23 \%$ \\
\hline Street pattern & $\begin{array}{c}\text { Grid with blok's circum- } \\
\text { ference length } \leq 600 \\
\text { meters }\end{array}$ & $\begin{array}{l}61 \% \text { not grid and do not } \\
\text { meet the standards of } \\
\text { blok's circumference } \\
\text { length } \leq 600 \text { meters }\end{array}$ \\
\hline Pedestrian way connectivity & $\geq 90 \%$ & $90 \%$ \\
\hline $\begin{array}{l}\text { Availability of pedestrian way } \\
\text { with shade }\end{array}$ & $\geq 75 \%$ & $50 \%$ \\
\hline $\begin{array}{l}\text { Percentage of total street } \\
\text { segments with safe cycling } \\
\text { conditions (speed } \leq 30 \mathrm{~km} / \\
\text { hour) }\end{array}$ & $\geq 90 \%$ & $35,37 \%$ \\
\hline Percentage of parking lot & $\leq 15 \%$ & $1,80 \%$ \\
\hline
\end{tabular}




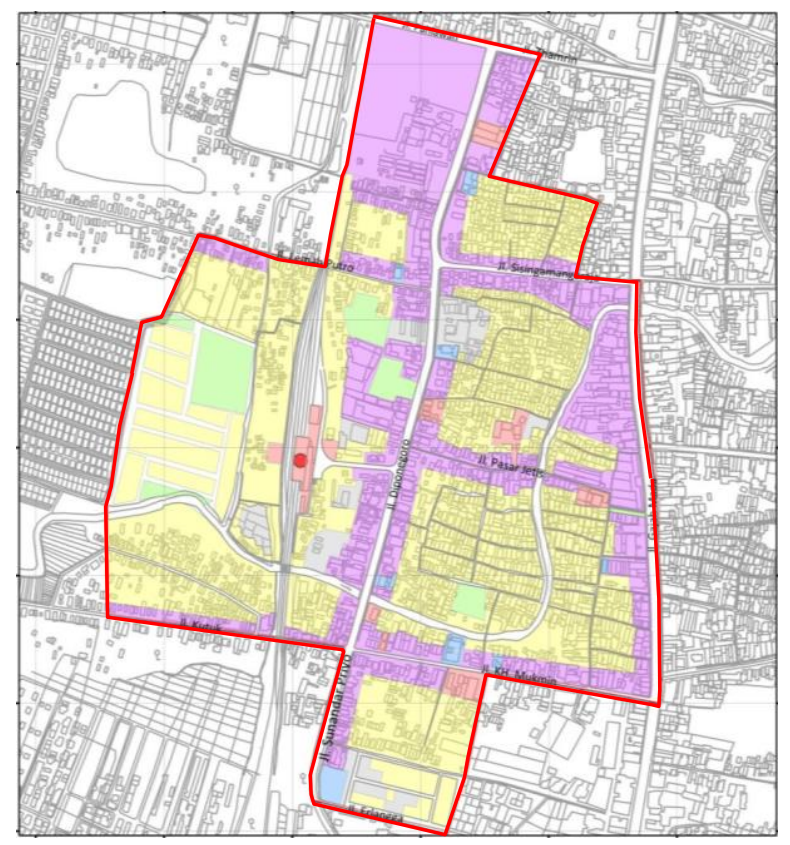

Figure 3. Land use in transit area of Sidoarjo Station Source: field survey, 2014 Note: yellow: residential; purple: commerce; blue: office; red: public facilities; green: green space; grey: open space.

5. Pedestrian-friendly TOD area design

The analysis showed that of the three variables in the indicator of pedestrianfriendly TOD area design, there is no variable that meets the standard. This result indicates that the design in transit area of Sidoarjo Station does not characterize the pedestrian-friendly design. This condition is also affected by the availability and quality of transportation facilities and infrastructure in TOD area, particularly pedestrian way. And from the analysis, we can see that there are $36 \%$ of passengers whose origin of movement $<800$ meters, but there is only $12 \%$ of passengers who choose to walk. Details can be seen in Table 6 and Figure 5.

From the walkthrough analysis, it is found that there is a tendency of inconvenience in the quality of pedestrian ways in transit area of Sidoarjo Station. It is reviewed from the width of pedestrian way, the availability of shelters in the form of trees and arcades along the pedestrian way, the presence of barriers, the continuity of sidewalks (both physical continuity and continuity of access upon the sidewalks), and the availability of road crossing facilities. It is also reviewed from the benchmark of orientation of buildings along the pedestrian way which includes the space between the buildings and the pedestrian ways, the absence of partition between buildings and pedestrian ways, and the visual penetration from the pedestrian ways into the building. 


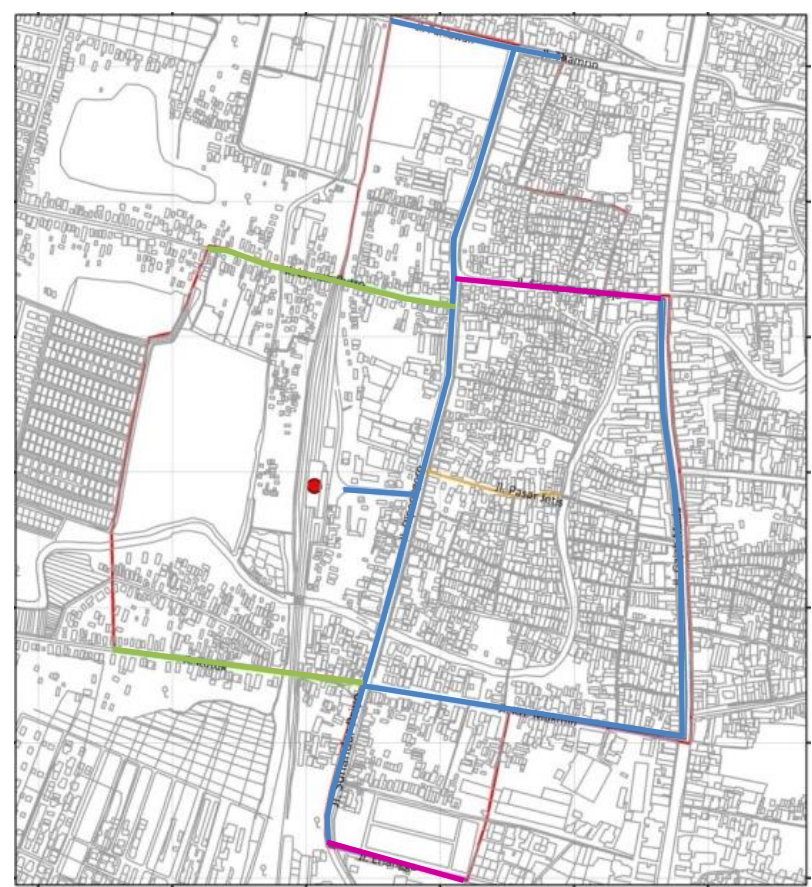

Figure 4. Road function in transit area of Sidoarjo Station Source: secundary survey, 2014

Note: blue: primary arteri; purple: secondary collector; green: local primary.

Table 6. Performance of transit area of Sidoarjo Station based on indicator of Pedestrian-Friendly TOD Area Design

\begin{tabular}{lcc}
\hline \multicolumn{1}{c}{ Variables } & Standards & Existing \\
\hline $\begin{array}{l}\text { Percentage of mode share to } \\
\text { reach station }\end{array}$ & Majority walking & $\begin{array}{c}12 \% \text { walking, 71\% private } \\
\text { car and motorcycle }\end{array}$ \\
$\begin{array}{l}\text { Comfortable level of pedestri- } \\
\text { an way }\end{array}$ & Comfort & $\begin{array}{c}12,5 \% \text { comfort } \\
\begin{array}{l}\text { Bulding orientation along the } \\
\text { pedestrian way }\end{array}\end{array}$ \\
\hline
\end{tabular}

Source: Analysis result, 2014

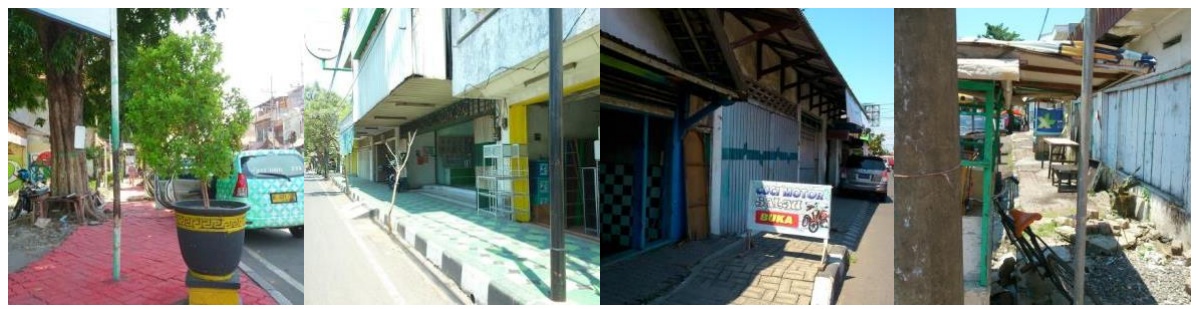

Figure 5. Condition of pedestrian way and building along the pedestrian way in transit area of Sidoarjo Station

Source: field survey, 2014 
Of the five indicators that are outlined into seventeen variables to analyze the performance of transit area of Sidoarjo Station as TOD community center with train as the main mode, it is concluded that there are only 4 variables that meet the standards, while the 13 variables do not meet the standards or do not characterize the TOD area. Thus, from the analysis, it can be concluded that the performance of transit area of Sidoarjo Station as a TOD area is only about $23.5 \%$. More details can be seen in Table 7.

Table 7. Performance of transit area of Sidoarjo Station as a community center TOD

\begin{tabular}{|c|c|c|}
\hline Indicators & Variables & $\begin{array}{l}\text { Transit area } \\
\text { performence }\end{array}$ \\
\hline \multirow{4}{*}{$\begin{array}{c}\text { Land use } \\
\text { density in TOD } \\
\text { area }\end{array}$} & BCR & $\sqrt{ }$ \\
\hline & Residential density & $\mathrm{x}$ \\
\hline & Number of floors of the building & $\mathrm{x}$ \\
\hline & Built land coverage & $\mathrm{x}$ \\
\hline \multirow{2}{*}{$\begin{array}{c}\text { Population } \\
\text { density in TOD } \\
\text { area }\end{array}$} & Population density & $\mathrm{x}$ \\
\hline & Employment density & $\mathrm{x}$ \\
\hline \multirow{2}{*}{$\begin{array}{l}\text { Land use di- } \\
\text { versity in TOD } \\
\text { area }\end{array}$} & Mix of uses ( $\%$ residential, $\%$ non residential) & $\mathrm{x}$ \\
\hline & Diversity of land price & $\mathrm{x}$ \\
\hline \multirow{6}{*}{$\begin{array}{l}\text { Transportation } \\
\text { facilities and } \\
\text { infrastructures } \\
\text { in TOD area }\end{array}$} & Percentage of road way area & $\sqrt{ }$ \\
\hline & Street pattern & $\mathrm{x}$ \\
\hline & Pedestrian way connectivity & $\sqrt{ }$ \\
\hline & Availability of pedestrian way with shade & $\mathrm{x}$ \\
\hline & $\begin{array}{l}\text { Percentage of total street segments with safe cycling } \\
\text { conditions (speed } \leq 30 \mathrm{~km} / \text { hour) }\end{array}$ & $\mathrm{x}$ \\
\hline & Percentage of parking lot & $\sqrt{ }$ \\
\hline \multirow{3}{*}{$\begin{array}{l}\text { Pedestrian- } \\
\text { friendly TOD } \\
\text { area design }\end{array}$} & Percentage of mode share to reach station & $\mathrm{x}$ \\
\hline & Comfortable level of pedestrian way & $\mathrm{x}$ \\
\hline & Bulding orientation along the pedestrian way & $\mathrm{x}$ \\
\hline
\end{tabular}

\section{CONCLUSIONS}

From the analysis and discussion, it is concluded that:

1. In general, the performance of transit area of Sidoarjo Station as a TOD area is relatively low at $23.5 \%$. Of the five indicators that are outlined into seventeen variables, it is concluded that there are only 4 variables that meet the standards: $\mathrm{BCR}$, percentage of road way area, pedestrian way connectivity, and percentage of parking lot.

2. Reviewed from the indicator of land use density, inter-building density (represented by BCR) has characterized the density of TOD community center, but the 
density dimension (represented by the number of floors of the building) and other density variables have not characterized the TOD area.

3. Reviewed from the indicator of population density in TOD area, the diversity of land use in TOD area and pedestrian-friendly TOD area design, there is none of the 3 variables that meet the standard and characterize the TOD area in transit area of Sidoarjo Station.

4. Reviewed from transportation facilities and infrastructure in TOD area, there are three variables that meet the standard and characterize TOD area in transit area of Sidoarjo Station. This result shows that, in general, transportation facilities and infrastructure in this area does not accommodate and is not oriented for the movement of non-motorized vehicles. This can be seen from the street pattern that tends to rotate (have no grid) and from the high number of road that are not safe for cyclists. In fact, the pedestrian ways are available and connected, but they still lack the quality of supporting facilities and infrastructure (seen from the availability of pedestrian way with shade and other aspects reviewed in the indicator of pedestrian-friendly TOD area design).

\section{ACKNOWLEDGMENT}

The writer shows the biggest gratitude for Allah SWT for all the blessings, grace, and guidance to complete this journal entitled "Analysis of The Performance of Transit Area of Sidoarjo Station as a Transit Oriented Development (TOD) Area". The authors would also like to thank Fast Track Scholarship of ITS, Government of Sidoarjo Regency, and PT Kereta Api Indonesia Daerah Operasi VIII East Java who have provided assistance in the completion of this report.

\section{REFERENCES}

Agustin, E. (2013), Penataan Koridor Jalan A. Yani Surabaya dengan Pendekatan Konsep "Sustainable Urban Street" sebagai Upaya Peningkatan Kualitas Lingkungan Koridor, Jurusan Arsitektur ITS, Surabaya.

Dittmar, H. and Ohland, G. (2004), The New Transit Town Best Practice in TransitOriented Development, Island Press, Wasingthon, DC.

Indrawati, S.W, et al. (2007), Handout Mata Kuliah Psikodiagnostik II (Observasi), Jurusan Psikologi Universitas Pendidikan Indonesia, Bandung.

Institute for Transportation and Development Policy. (2014), TOD Standard, Despacio, New York.

Isa, M. H. (2014), Arahan Pengembangan Kawasan Transit Berbasis Transit Oriented Development (TOD) dalam Mendorong Penggunaan Kereta Komuter Koridor Surabaya-Sidoarjo, Program Studi Perencanaan Wilayah dan Kota ITS, Surabaya.

Kusbiantoro, B. S., et al. (2007), Kebutuhan dan Peluang Pengembangan Fasilitas Pedesterian pada Sistem Jalan di Perkantoran, Jurnal Perencanaan Wilayah dan Kota, 18(2), 74-102, Institut Teknologi Bandung, Bandung. 
National Development Planning Agency (2012), Arah Kebijakan dan Strategi Pengembangan Transportasi di Kawasan Perkotaan Indonesia, Direktorat Transportasi - Badan Perencanaan Pembangunan Nasional, Jakarta.

Surabaya Development Planning Agency (2013), Pengembangan Transportasi di Kota Surabaya, Pemerintah Kota Surabaya, Surabaya.

The City of Calgary Land Use Planning and Policy (2004), TOD Best Practice Handbook.

Walpole, R.E. (1995), Pengantar Statistika, Gramedia Pustaka Utama, Jakarta.

Widyahari, N. L. A. and Indradjati, P. N. (2014), Potensi dan Peluang Pengembangan Transit-Oriented Development di Kawasan Perkotaan Cekungan Bandung, Jurnal Perencanaan Wilayah dan Kota B SAPPK, 3(2), Institut Teknologi Bandung, Bandung.

World Bank (2014), Surabaya Urban CorridorVisioning Workshop, Bank Dunia kerja sama dengan Hansen Partnership dan SUTD, Surabaya. 
Isa, Pamungkas, Suprihardjo: ANALYSIS OF THE PERFORMANCE OF TRANSIT AREA OF SIDOARJO

This page intentionally left blank 